\title{
REVIEW
}

\section{Biomarkers in biological fluids for dementia with Lewy bodies}

Sebastian Schade ${ }^{1,2}$ and Brit Mollenhauer $1,3,4^{*}$

\begin{abstract}
Dementia with Lewy bodies (DLB) has become the second most common neurodegenerative dementia due to demographic ageing. Differential diagnosis is still troublesome especially in early stages of the disease, since there is a great clinical and neuropathological overlap primarily with Alzheimer's disease and Parkinson's disease. Therefore, more specific biomarkers, not only for scientific reasons but also for clinical therapeutic decision-making, are urgently needed. In this review, we summarize the knowledge on fluid biomarkers for DLB, derived predominantly from cerebrospinal fluid. We discuss the value of well-defined markers ( $\beta$-amyloid, (phosphorylated) tau, $\boldsymbol{a}$-synuclein) as well as some promising 'upcoming' substances, which still have to be further evaluated.
\end{abstract}

\section{Introduction}

The isolation and successful detection of soluble $\beta$-amyloid (A $\beta$ ) from biological fluids in 1992 [1] revolutionized our knowledge of the connection between molecular pathology and cerebrospinal fluid (CSF) biomarkers. The progressing elucidation of the underlying and overlapping molecular pathologies of several neurodegenerative diseases, including Alzheimer's disease (AD) and Parkinson's disease (PD), has resulted in new biomarkers, which are urgently needed for more accurate diagnosis and as possible endpoints for clinical trials with future neuropreventive strategies. Thanks to vigorous defining criteria, the stratification of dementia with Lewy-bodies (DLB) as a molecular and clinical 'in-between' disorder has been pursued, but it still has clinical and neuropathological overlap with $\mathrm{AD}$ and PD [2,3], which makes its early diagnosis difficult. While hallucinations in AD predict the coincidence of DLB with a specificity of $100 \%$ [4], the presence of non-motor symptoms, decreased dopamine transporter imaging [5] and response to dopaminergic therapy does not help to separate DLB from PD since only about 36\% of subjects can be clinically classified as 'responders' using the L-dopa challenge $[6,7]$.

The quantification of $\mathrm{A} \beta 1-42$ in CSF in combination with total and/or phosphorylated tau protein was recently

\footnotetext{
* Correspondence: brit.mollenhauer@paracelsus-kliniken.de

${ }^{1}$ Paracelsus-Elena-Klinik, Klinikstraße 16, D-34128 Kassel, Germany

${ }^{3}$ Department of Neurosurgery, University Medical Center, Georg-August

University, Robert-Koch Straße 40, 37075 Göttingen, Germany

Full list of author information is available at the end of the article
}

(together with positron emission tomography and structural magnetic resonance imaging) included in proposed research criteria for the clinical diagnosis of $\mathrm{AD}$ [8]. Here, reduced $A \beta 1-42$ and increased total/phosphorylated tau protein in CSF correlate with neuropathologic features of the disease - that is, $A \beta$ plaques and neurofibrillary tangles and neuronal loss - as well as clinical symptoms and disease intensity [9]. This CSF signature is a good predictor for cognitive decline in mild cognitive impairment [10] with high predictive value for identifying converters into overt dementia [11].

In $\mathrm{PD}$, the underlying pathology is characterized by presynaptic $\alpha$-synuclein (aSyn) aggregates and synapse rarefaction. Cognitive decline in PD occurs due to various reasons leading to destruction of essential networks [12]. The main question of whether and how much AD and aSyn pathology each contribute to cognitive decline in PD remains disputable [13]. A majority of DLB patients show increased cortical ${ }^{11} \mathrm{C}$-PIB binding, similar to AD [14,15]. This suggests that DLB is actually a dementia associated with both aSyn and $A \beta$ pathology, thereby possibly explaining its aggressive nature. PD with dementia (PDD), in contrast, shows a reduced prevalence of amyloid plaques and lower levels of cortical ${ }^{11} \mathrm{C}$-PIB binding than DLB [14-16]. This finding suggests that the dementia of PD subjects is more likely due to a specific aSyn pathology rather than only an overlap of other pathologies, in agreement with post-mortem observations $[17,18]$. Others suggest, however, that the neuropathological correlate of PDD is a combination 
of different pathologies rather than the severity of any single pathology [3]. In addition, it has been proposed that the presence of $A \beta$ triggers cognitive decline and dementia in PDD and DLB, but does not directly determine its nature [19]. In this context, it should be highlighted that incidental $A \beta$ can be detected on occasion in healthy controls as well as in older subjects with PD [15], and decreased levels of CSF A $\beta 1-42$ have been observed in recently diagnosed PD patients [20] and in patients with and without cognitive decline $[21,22]$; this suggests that amyloid pathology does not have a single causative role in dementia. Furthermore, it has been shown that PD cases without dementia, but progression of cortical amyloid, show a faster cognitive deterioration than patients who are without $A \beta$ deposits at baseline [23]. This is supported by a recent study that showed that low levels of CSF A $1-42$ predict early-onset cognitive decline [24].

Thus, one current major problem is the overlapping neuropathology and the as yet incompletely understood molecular constituents of the pathological changes. It is expected that in the next years many more neuropathological entities will be identified and characterized at the molecular level, which will also influence our thinking of clinical phenotyping and the selection of biomarker candidates in the future [25].

\section{Biomarkers in dementia with Lewy bodies}

In addition to imaging biomarkers (see article by Mak and colleagues within this special series [26]), biomarkers in DLB include functional marker candidates, like electroencephalography slowing [27] and the detection of rapid eye movement sleep behaviour disorder and other sleep disturbances with polysomnography [28].

Dopamine transporter imaging studies are helpful in the differential diagnosis of $\mathrm{AD}$, but are expensive and not widely available. A biological fluid marker would be more widely available (when shipped to a central laboratory), cheap, and have low safety concerns. Optimal marker candidates reflect a process proximal to the specific pathology; therefore, most studies on neurodegenerative disorders rely on marker candidates in the CSF. The 'CSF analytic area' comprises the area of the brain directly contributing to CSF composition, which incorporates the basal ganglia and the brainstem as main sites of interest in movement disorders. aSyn pathology in DLB (and PD) has also been shown in the periphery [29], however, which could enable the detection of a marker in peripheral biological fluids; for example, in blood or saliva [30]. So far, studies have been discrepant and need further validation (see below).

\section{Cerebrospinal fluid biomarkers in dementia with Lewy bodies}

The composition and alteration of CSF proteins, which might be disease-specific, underlines the value of CSF analysis as a diagnostic tool. Nevertheless, known and potential confounding factors need to be taken into account in any biological fluid study, such as protease activity, blood contamination - which occurs in 10 to $20 \%$ of lumbar punctures - and adhesion, especially of lipophilic proteins to certain external surfaces like polypropylene and glass. The adherence of standard operating procedures is essential to avoid false positive or negative findings.

\section{Alzheimer's disease biomarkers in dementia with Lewy bodies}

The combination of decreased $\mathrm{A} \beta$ peptides and increased total/phosphorylated tau protein in CSF of AD subjects has shown diagnostic sensitivity and specificity above $80 \%$ in most studies [9].

Enzymatic cleavage of the $120 \mathrm{kDa}$ transmembrane amyloid precursor protein leads to different fragments of the $A \beta$ peptide [31]. A $\beta$ seems to be important for the processing of information between neurons and is variably prone to aggregate and form plaques [32]. Amyloid plaques are found in the brain of patients with $\mathrm{AD}$ and DLB [31,33] and contain primarily carboxy-terminally elongated forms of $A \beta$ peptides, such as the fragment A $\beta 1-42$.

As in AD, CSF levels of A $\beta 1-42$ in DLB are regularly decreased compared to non-demented controls [34]. The correlation of decreased CSF A $\beta$ values was shown by in vivo brain amyloid load in $\mathrm{AD}$ [35] but also appeared to be non-specifically decreased in other disorders without plaque pathology [36], which might be due to interindividual differences in the amount of amyloidogenic amyloid precursor protein processing. Attempts to normalize $\mathrm{A} \beta 1-42$ concentrations to $A \beta 1-40$ (A $\beta 1-42 / A \beta 1-40$ ratio) have been promising in terms of differentiating $A D$ from DLB when compared with measuring these biomarkers individually [37]. Nevertheless, most studies could not define valuable cutoff scores to distinguish AD and DLB [38,39], including one large autopsy study [40]. One reason might be the heterogeneity and possible interaction of neuropathological alterations in DLB. At least one study showed significantly lower CSF A $\beta 1-42$ in DLB patients with senile plaques compared with DLB patients without senile plaques [41]. Another reason could be that a correlation between phosphorylated tau protein in CSF and its neuropathological equivalent (neurofibrillary tangles) was not found in patients with DLB [41].

Other fragments, isoforms and posttranslational modifications of $A \beta$ peptides have also been proposed as CSF biomarkers for DLB. The oxidized version of $A \beta 1-40$ $\left(\mathrm{A} \beta 1-40^{\mathrm{ox}}\right)$, containing $\alpha$-helical structures [42], has been shown to be increased in DLB patients compared with PDD patients and non-demented disease controls, which recently also has been shown in autopsy-proven AD and 
DLB [43]. This finding has been proposed to be a pathophysiological metabolism of A $\beta 1-40$ specific to DLB, but needs to be replicated by independent groups and using alternative approaches. Other $A \beta$ isoforms, such as $A \beta 1-37$ and $A \beta 1-38$, are still a focus of research, but need to be better characterized [42]. Further posttranslational modifications (for example, fragmented forms of $A \beta$ ) possibly reflecting more disease-specific changes are currently been investigated by different groups [44].

The natively unfolded microtubule-associated phosphoprotein $68 \mathrm{kDa}$ tau is important for the stabilization of microtubules [45]. Neuronal cells in AD contain pairwise helical protein filaments (neurofibrillary tangles) $[46,47]$ that are insoluble, stable polymers of the low molecular weight tau protein [48].

Intracellular tau protein is elevated in CSF of $\mathrm{AD}$ subjects and excessively increases in conditions with rapid neuronal loss - for example, Creutzfeldt-Jakob disease. In DLB, levels of CSF tau protein are lower compared to $\mathrm{AD}$ [40] and higher compared to PD and PDD [49]. Interestingly, patients with a diagnosis of 'probable DLB' according to the classification criteria [5] (which should be more accurate), tend to have even lower CSF tau protein levels [49].

Hyperphosphorylation of tau protein promotes its aggregation into neurofibrillary tangles. Some CSF studies have revealed better specificity for the discrimination of $\mathrm{AD}$ when using p-tau protein 181 rather than total tau protein [50]. Since the phosphorylation of tau protein in brain occurs to a lesser extent in DLB [51,52], the quantification of phosphorylated tau species in CSF may serve as a specific marker to discriminate AD from DLB [50,53]. Other phosphorylation sites of tau protein in CSF have been analyzed for their diagnostic value, showing similar results [54-57] (Table 1).

\section{Parkinson's disease biomarkers in dementia with Lewy bodies}

The 140 amino acid aSyn is predominantly expressed in the pre-synapses supporting the formation and transport of vesicles [58] and is the major constituent of Lewy bodies, the generally accepted pathological hallmark of PD and DLB, and it is also present in the glial cytoplasmic inclusions of multiple system atrophy [59,60].

Full-length aSyn has been detected in extracellular biological fluids, including plasma, conditioned cell media and most recently saliva $[61,62]$. The quantification of extracellular aSyn has been proposed as a potential biomarker for synuclein-related disorders: most investigators have shown a reduction of CSF total aSyn in the synuclein-related disorders PD, DLB and multiple system atrophy [63-65]. A rather small study, but one that strictly controlled several possible confounders (for example, blood contamination, diurnal variation, food intake, rostro-caudal CSF gradient, gender, age), showed contradictory results, with an increase of aSyn in DLB compared with healthy controls and AD patients [66]. These results need to be replicated, but possible confounding factors (for example, blood contamination, subject selection and technical/methodological differences, especially choosing the right antibodies to ensure accurate measurement of total aSyn rather than its fractions) should be even more rigorously taken into account when conducting further studies.

The underlying mechanism of decreasing CSF aSyn remains unclear to date, and could result from various scenarios, such as the reduction of aSyn release into the extracellular space due to intracellular aggregation; alteration of SNCA gene transcription [67], mRNA splicing [68] or protein processing [69]; a higher CSF flow

Table 1 Sumary of neuropathologic, clinical, imaging and fluid markers in dementia with Lewy bodies, Parkinson's disease and Alzheimer's disease

\begin{tabular}{|c|c|c|c|c|c|}
\hline & $A D$ & $A D$ and DLB & DLB & DLB and $P D(D)$ & PD \\
\hline \multirow[t]{2}{*}{ Neuropathology } & & Neurofibrillary tangles & & Lewy bodies & \\
\hline & & Amyloid plaques & & & \\
\hline \multirow[t]{3}{*}{ Clinical symptoms } & & Cognitive decline & Spontaneous hallucinations & Cognitive decline & \\
\hline & & & & RBD & \\
\hline & & & & L-Dopa response & \\
\hline Nuclear imaging & & PIB binding $\uparrow$ & & DAT $\downarrow$ & \\
\hline \multirow[t]{3}{*}{ CSF biomarkers } & $\operatorname{tau} \uparrow$ & $\beta$-Amyloid 1-42 $\downarrow$ & $\beta$-Amyloid $1-40^{\circ \times} \uparrow$ & a-Synuclein $\downarrow$ & a-Synuclein $\downarrow$ \\
\hline & $\mathrm{p}$-tau $\uparrow$ & Soluble NG2 $\downarrow$ & CART $\downarrow$ & Neurosin $\downarrow$ & Oligomeric a-synuclein $\uparrow$ \\
\hline & & & $N F \uparrow$ & & \\
\hline \multirow[t]{2}{*}{ Serum biomarkers } & & & $\mathrm{H}-\mathrm{FABP} \uparrow$ & & \\
\hline & & & $\mathrm{Ca} / \mathrm{Mg} \uparrow$ & & \\
\hline
\end{tabular}

AD, Alzheimer' disease; CART, cocaine and amphetamine regulated transcript; CSF, cerebrospinal fluid; DAT, dopamine transporter imaging; DLB, dementia with Lewy bodies; H-FABP, heart-type fatty acid binding protein; NF, neurofilament; NG2, Neuron glia 2; PD, Parkinson's disease; PDD, Parkinson's disease with dementia; PIB, Pittsburgh compound B; p-tau, phosphorylated tau protein; RBD, REM sleep behaviour disorder. 
with lower permeation of plasma aSyn into CSF; an enhanced clearance rate of aSyn from CSF [70]; or as yet unidentified factors or any combination of mechanisms [65]. Furthermore, aSyn might intracellularly aggregate in Lewy bodies and presynaptic terminals (thereby possibly decreasing the extracellular amount), since results from studies on aSyn in patients with $\mathrm{AD}$ have been somewhat heterogeneous, perhaps indicating a subgroup of AD patients with additional Lewy body pathology and a clear mismatch of high p-tau protein 181 and low aSyn CSF levels [71]. A possible explanation for increased CSF aSyn levels (in addition to the inverse of the mechanisms described above) might be that they partly reflect neuronal and/or axonal injury, which would be in line with a correlation of total tau values and aSyn in CSF samples of AD patients [71], although a correlation between aSyn levels and regional brain atrophy could not be detected [72].

Whereas methods for quantifying total aSyn detect mono- and oligomeric forms, an oligomer-specific aSyn assay has been established that uses the same monoclonal antibody for both capture and detection [73]. Oligomeric aSyn comprises up to $10 \%$ of the total aSyn content of CSF. Independent studies show an increase of CSF oligomeric aSyn in PD compared with $\mathrm{AD}$, progressive supranuclear palsy and controls [73,74]. Together with the reduced CSF total aSyn, the ratio of oligomeric to total aSyn had a sensitivity of $89.3 \%$ and a specificity of $90.6 \%$ for the diagnosis of PD in this study [74].

Further investigation of the specificity of the antibodies and total and oligomeric aSyn enzyme-linked immunoassay techniques are needed, as are independent studies on other posttranslationally modified aSyn species, studies quantifying CSF aSyn in longitudinal patient cohorts, as well as studies of aSyn in other biological fluids.

Neurosin, a protein suggested to cleave aSyn and thereby potentially with a major role in the pathomechanisms of diseases associated with aSyn pathology, was shown to be reduced in CSF of patients with synuclein-related disorders compared with healthy controls and patients with AD. The lowest levels have been found in patients with DLB, thereby offering a new option for a potential biomarker [75].

Other PD biomarkers in CSF have not yet been investigated in DLB, such as the multifunctional protein DJ-1 and its oxidized forms involved in many cellular processes [76-78], and other synaptic proteins.

\section{Other potential biomarkers for dementia with Lewy bodies \\ Neurofilaments}

Neurofilaments (NFs) are involved in structural integrity and cell/organelle motility along the axons and determine axon calibre. CSF levels of NFs have been found to be elevated in DLB, but no significant differences have been observed in comparison with other dementias. Therefore, NFs seem to provide only a general hint of neuronal and axonal dysfunction without differential value for separating DLB from other disorders [79]. But data are still rare. In particular, subsets of NFs need to be evaluated further, since various types of neurons are affected in the different forms of dementia, perhaps meaning that different patterns of elevated NFs are potential biomarkers for differential diagnosis of dementias. Three different subunits of NF (light (NF-L), medium (NF-M) and heavy (NF-H)) have been defined. The filament is made up of one NF-L and either NF-M or NF-H arranged head to tail $[80,81]$.

\section{Fatty acid-binding proteins}

Fatty acid-binding proteins (FABPs) are a family of small intracellular proteins that facilitate the transport of fatty acids between the cell membrane and different organelles [82]. Lower levels of heart-type FABP have been reported in brains from patients with Down's syndrome and AD [83]. Serum FABP levels are elevated in a quite distinct manner in DLB $[84,85]$.

\section{Other potential biomarkers}

On the basis of stronger pathological involvement of dopaminergic and serotonergic pathways in DLB than in $\mathrm{AD}$, several neurotransmitters and their metabolites have been investigated. Reduced levels of the metabolites homovanillic acid, 5- hydroxyindolacetic acid and 3methoxy-4-hydroxyphenylethyleneglycol have been found in DLB compared with AD [86]. Especially the latter, in combination with total tau protein, $p$-tau and $A \beta 1-42$, could increase the sensitivity and specificity of discriminating those entities [87].

The chondroitinase sulphate proteoglycan Neuron glia 2 is a proteoglycan involved in several basic cellular mechanisms of pericytes as well as oligodentrocyte progenitor cells and its soluble form can be detected in CSF. Lower levels of soluble Neuron glia 2 have been found in CSF of patients with $A D$ and DLB, but not in patients with PD or PDD, thereby implicating some kind of association with the accumulation of $A \beta$ rather than aSyn. Results are preliminary and mechanisms far from being understood, but further investigations seem to be worthwhile [88].

Cocaine and amphetamine regulated transcript is a neuropeptide which is expressed selectively in the hypothalamus and was recently found to be present at significantly reduced levels in the CSF of DLB patients compared with controls and patients with AD [89]. Further studies are needed to confirm these preliminary data resulting from a rather small patient sample. Similarly, elevated levels of calcium and magnesium in CSF as well as of magnesium in blood were found by a Swedish study group, which used mass spectrometry to compare 
DLB patients with healthy controls and patients with $\mathrm{AD}$ [90]. These findings have to be replicated by independent groups. It is noteworthy that following our growing knowledge of molecular genetics in the field of neurodegenerative diseases, there have been high expectations that some gene products (for example, DJ-1, glucocerebrosidase) might be of use as biomarkers. Unfortunately, results have been either heterogeneous or rare in terms of DLB [91].

Finally, new diagnostic proteins might be discovered by proteomic studies. So far, some 'protein peaks' have been found as potential differential biomarkers, but these have either not been attributed to specific proteins [92] or have not been confirmed by further studies [93]. It is problematic that there is a lack of consistency across proteomic studies, which might be due to strong variations during sample preparation prior to the proteomic experiment itself (for example, degradation of proteins by storage material, contamination with blood) [94]. Therefore, standardized procedures are needed.

\section{Conclusion}

This review summarizes current studies on neurochemical marker candidates for DLB. Overall, it is clear that DLB is a disease 'in between' $\mathrm{AD}$ and $\mathrm{PD}$, which is supported by clinical, imaging, neuropathological and neurochemical studies. Biomarker candidates from the AD and PD fields have been tested in DLB, but only a few have been shown to more specifically reflect the underlying DLB. Most of the markers reflect neuropathological features, but as long our discrimination of PDD and DLB is based only on an arbitrary 'one-year rule' without separation based on molecular pathology, biomarker studies with DLB subjects will be hampered [95].

Note: This article is part of a series on Lewy Body Dementia,

edited by lan McKeith and James Galvin. Other articles in this series

can be found at http://alzres.com/series/LewyBodyDementia.

\begin{abstract}
Abbreviations
AB: $\beta$-amyloid; AD: Alzheimer' disease; aSyn: a-synuclein; CSF: Cerebrospinal fluid; DLB: Dementia with Lewy bodies; FABP: Fatty acid-binding protein; NF: Neurofilament; PD: Parkinson's disease; PDD: Parkinson's disease with dementia.
\end{abstract}

\section{Competing interests}

The authors declare that they have no competing interests.

\section{Author details}

'Paracelsus-Elena-Klinik, Klinikstraße 16, D-34128 Kassel, Germany. ${ }^{2}$ Department of Clinical Neurophysiology, University Medical Center, Georg-August University, Robert-Koch Straße 40, 37075 Göttingen, Germany. ${ }^{3}$ Department of Neurosurgery, University Medical Center, Georg-August University, Robert-Koch Straße 40, 37075 Göttingen, Germany. ${ }^{4}$ Department of Neuropathology, University Medical Center, Georg-August University, Robert-Koch Straße 40, 37075 Göttingen, Germany.
Published online: 16 October 2014

\section{References}

1. Seubert P, Vigo-Pelfrey C, Esch F, Lee M, Dovey H, Davis D, Sinha S, Schlossmacher M, Whaley J, Swindlehurst C, McCormack R, Wolfert R, Selkoe D, Lieberburg I, Schenk D: Isolation and quantification of soluble Alzheimer's beta-peptide from biological fluids. Nature 1992, 359:325-327.

2. Noe E, Marder K, Bell KL, Jacobs DM, Manly JJ, Stern Y: Comparison of dementia with Lewy bodies to Alzheimer's disease and Parkinson's disease with dementia. Mov Disord 2004, 19:60-67.

3. Compta Y, Parkkinen L, O'Sullivan SS, Vandrovcova J, Holton JL, Collins C, Lashley T, Kallis C, Williams DR, de Silva R, Lees AJ, Revesz T: Lewy- and Alzheimer-type pathologies in Parkinson's disease dementia: which is more important? Brain 2011, 134:1493-1505.

4. Toledo JB, Cairns NJ, Da X, Chen K, Carter D, Fleisher A, Householder E, Ayutyanont N, Roontiva A, Bauer RJ, Eisen P, Shaw LM, Davatzikos C, Weiner MW, Reiman EM, Morris JC, Trojanowski JQ, Alzheimer's Disease Neuroimaging Initiative: Clinical and multimodal biomarker correlates of ADNI neuropathological findings. Acta Neuropathol Commun 2013, 1:65.

5. McKeith IG, Dickson DW, Lowe J, Emre M, O'Brien JT, Feldman H, Cummings J, Duda JE, Lippa C, Perry EK, Aarsland D, Arai H, Ballard CG, Boeve B, Burn DJ, Costa D, Del Ser T, Dubois B, Galasko D, Gauthier S, Goetz CG, Gomez-Tortosa E, Halliday G, Hansen LA, Hardy J, Iwatsubo T, Kalaria RN, Kaufer D, Kenny RA, Korczyn A, et al: Diagnosis and management of dementia with Lewy bodies: third report of the DLB consortium. Neurology 2005, 65:1863-1872.

6. Molloy S, McKeith IG, O'Brien JT, Burn DJ: The role of levodopa in the management of dementia with Lewy bodies. J Neurol Neurosurg Psychiatry 2005, 76:1200-1203.

7. Bonelli SB, Ransmayr G, Steffelbauer M, Lukas T, Lampl C, Deibl M: L-Dopa responsiveness in dementia with Lewy bodies, Parkinson disease with and without dementia. Neurology 2004, 63:376-378.

8. Dubois B, Feldman HH, Jacova C, Dekosky ST, Barberger-Gateau P, Cummings J, Delacourte A, Galasko D, Gauthier S, Jicha G, Meguro K, O'Brien J, Pasquier F, Robert P, Rossor M, Salloway S, Stern Y, Visser PJ, Scheltens P: Research criteria for the diagnosis of Alzheimer's disease: revising the NINCDS-ADRDA criteria. Lancet Neurol 2007, 6:734-746.

9. Blennow K, Hampel H, Weiner M, Zetterberg H: Cerebrospinal fluid and plasma biomarkers in Alzheimer disease. Nat Rev Neurol 2010, 6:131-144.

10. Hansson O, Zetterberg H, Buchhave P, Londos E, Blennow K, Minthon L: Association between CSF biomarkers and incipient Alzheimer's disease in patients with mild cognitive impairment: a follow-up study. Lancet Neurol 2006, 5:228-234.

11. Buchhave $P$, Minthon L, Zetterberg H, Wallin AK, Blennow K, Hansson O: Cerebrospinal fluid levels of beta-amyloid 1-42, but not of tau, are fully changed already 5 to 10 years before the onset of Alzheimer dementia. Arch Gen Psychiatry 2012, 69:98-106.

12. Jellinger KA: Neurobiology of cognitive impairment in Parkinson's disease. Expert Rev Neurother 2012, 12:1451-1466.

13. Mollenhauer B, Schulz-Schaeffer W, Schlossmacher M: Synaptic alpha-synuclein pathology as the likely cause of Parkinson's disease dementia. Lancet Neurol 2011, 10:68-69.

14. Edison P, Rowe CC, Rinne JO, Ng S, Ahmed I, Kemppainen N, Villemagne VL, O'Keefe G, Nagren K, Chaudhury KR, Masters CL, Brooks DJ: Amyloid load in Parkinson's disease dementia and Lewy body dementia measured with [11C]PIB positron emission tomography. J Neurol Neurosurg Psychiatry 2008, 79:1331-1338.

15. Gomperts SN, Rentz DM, Moran E, Becker JA, Locascio JJ, Klunk WE, Mathis CA, Elmaleh DR, Shoup T, Fischman AJ, Hyman BT, Growdon JH, Johnson KA: Imaging amyloid deposition in Lewy body diseases. Neurology 2008, 71:903-910

16. Jokinen P, Scheinin N, Aalto S, Nagren K, Savisto N, Parkkola R, Rokka J, Haaparanta M, Roytta M, Rinne JO: [(11)C]PIB-, [(18)F]FDG-PET and MRI imaging in patients with Parkinson's disease with and without dementia. Parkinsonism Relat Disord 2010, 16:666-670.

17. Aarsland D, Perry R, Brown A, Larsen JP, Ballard C: Neuropathology of dementia in Parkinson's disease: a prospective, community-based study. Ann Neurol 2005, 58:773-776. 
18. Kramer ML, Schulz-Schaeffer WJ: Presynaptic alpha-synuclein aggregates, not Lewy bodies, cause neurodegeneration in dementia with Lewy bodies. J Neurosci 2007, 27:1405-1410.

19. Gomperts SN, Locascio JJ, Marquie M, Santarlasci AL, Rentz DM, Maye J, Johnson KA, Growdon JH: Brain amyloid and cognition in Lewy body diseases. Mov Disord 2012, 27:965-973.

20. Alves G, Bronnick K, Aarsland D, Blennow K, Zetterberg H, Ballard C, Kurz MW, Andreasson U, Tysnes OB, Larsen JP, Mulugeta E: CSF amyloid-beta and tau proteins, and cognitive performance, in early and untreated Parkinson's disease: the Norwegian ParkWest study. J Neurol Neurosurg Psychiatry 2010, 81:1080-1086.

21. Compta Y, Marti MJ, Ibarretxe-Bilbao N, Junque C, Valldeoriola F, Munoz E, Ezquerra M, Rios J, Tolosa E: Cerebrospinal tau, phospho-tau, and beta-amyloid and neuropsychological functions in Parkinson's disease. Mov Disord 2009, 24:2203-2210.

22. Montine TJ, Shi M, Quinn JF, Peskind ER, Craft S, Ginghina C, Chung KA, Kim H, Galasko DR, Jankovic J, Zabetian CP, Leverenz JB, Zhang J: CSF Abeta(42) and tau in Parkinson's disease with cognitive impairment. Mov Disord 2010, 25:2682-2685.

23. Gomperts SN, Locascio JJ, Rentz D, Santarlasci A, Marquie M, Johnson KA, Growdon JH: Amyloid is linked to cognitive decline in patients with Parkinson disease without dementia. Neurology 2013, 80:85-91.

24. Alves G, Lange J, Blennow K, Zetterberg H, Andreasson U, Forland MG, Tysnes OB, Larsen JP, Pedersen KF: CSF Abeta42 predicts early-onset dementia in Parkinson disease. Neurology 2014, 82:1784-1790.

25. Borroni B, Alberici A, Archetti S, Magnani E, Di Luca M, Padovani A: New insights into biological markers of frontotemporal lobar degeneration spectrum. Curr Med Chem 2010, 17:1002-1009.

26. Mak E, Su L, Williams GB, O'Brien JT: Neuroimaging characteristics of dementia with Lewy bodies. Alzheimers Res Ther 2014, 6:18

27. Bonanni L, Thomas A, Tiraboschi P, Perfetti B, Varanese S, Onofrj M: EEG comparisons in early Alzheimer's disease, dementia with Lewy bodies and Parkinson's disease with dementia patients with a 2-year follow-up. Brain 2008, 131:690-705.

28. Terzaghi M, Arnaldi D, Rizzetti MC, Minafra B, Cremascoli R, Rustioni V, Zangaglia R, Pasotti C, Sinforiani E, Pacchetti C, Manni R: Analysis of video-polysomnographic sleep findings in dementia with Lewy bodies. Mov Disord 2013, 28:1416-1423.

29. Braak H, de Vos RAl, Bohl J, Del Tredici K: Gastric [alpha]-synuclein immunoreactive inclusions in Meissner's and Auerbach's plexuses in cases staged for Parkinson's disease-related brain pathology. Neurosci Lett 2006, 396:67-72

30. Devic I, Hwang H, Edgar JS, Izutsu K, Presland R, Pan C, Goodlett DR, Wang Y, Armaly J, Tumas V, Zabetian CP, Leverenz JB, Shi M, Zhang J: Salivary alpha-synuclein and DJ-1: potential biomarkers for Parkinson's disease. Brain 2011, 134:e178.

31. Glenner GG, Wong CW, Quaranta V, Eanes ED: The amyloid deposits in Alzheimer's disease: their nature and pathogenesis. Appl Pathol 1984, 2:357-369.

32. Guntert A, Dobeli $H$, Bohrmann B: High sensitivity analysis of amyloid-beta peptide composition in amyloid deposits from human and PS2APP mouse brain. Neuroscience 2006, 143:461-475.

33. Jendroska K, Kashiwagi M, Sassoon J, Daniel SE: Amyloid beta-peptide and its relationship with dementia in Lewy body disease. J Neural Transm Suppl 1997, 51:137-144.

34. Kanemaru K, Kameda N, Yamanouchi H: Decreased CSF amyloid beta42 and normal tau levels in dementia with Lewy bodies. Neurology 2000 54:1875-1876.

35. Fagan AM, Mintun MA, Mach RH, Lee SY, Dence CS, Shah AR, LaRossa GN, Spinner ML, Klunk WE, Mathis CA, DeKosky ST, Morris JC, Holtzman DM: Inverse relation between in vivo amyloid imaging load and cerebrospinal fluid Abeta42 in humans. Ann Neurol 2006, 59:512-519.

36. Mollenhauer B, Esselmann H, Roeber S, Schulz-Schaeffer WJ, Trenkwalder C, Bibl M, Steinacker P, Kretzschmar HA, Wiltfang J, Otto M: Different CSF beta-amyloid processing in Alzheimer's and Creutzfeldt-Jakob disease. J Neural Transm 2011, 118:691-697.

37. Nutu M, Zetterberg H, Londos E, Minthon L, Nagga K, Blennow K, Hansson O, Ohrfelt A: Evaluation of the cerebrospinal fluid amyloid-beta1-42/ amyloid-beta 1-40 ratio measured by alpha-LISA to distinguish Alzheimer's disease from other dementia disorders. Dement Geriatr Cogn Disord 2013, 36:99-110.
38. Vanderstichele $H$, De Vreese $K$, Blennow K, Andreasen N, Sindic C, Ivanoiu A, Hampel H, Burger K, Parnetti L, Lanari A, Padovani A, DiLuca M, Blaser M, Olsson $A O$, Pottel $H$, Hulstaert F, Vanmechelen E: Analytical performance and clinical utility of the INNOTEST PHOSPHO-TAU181P assay for discrimination between Alzheimer's disease and dementia with Lewy bodies. Clin Chem Lab Med 2006, 44:1472-1480.

39. Mollenhauer B, Bibl M, Wiltfang J, Steinacker P, Ciesielczyk B, Neubert K, Trenkwalder C, Otto M: Total tau protein, phosphorylated tau (181p) protein, beta-amyloid(1-42), and beta-amyloid(1-40) in cerebrospinal fluid of patients with dementia with Lewy bodies. Clin Chem Lab Med 2006, 44:192-195.

40. Clark CM, Xie S, Chittams J, Ewbank D, Peskind E, Galasko D, Morris JC, McKeel DW Jr, Farlow M, Weitlauf SL, Quinn J, Kaye J, Knopman D, Arai H, Doody RS, DeCarli C, Leight S, Lee VM, Trojanowski JQ: Cerebrospinal fluid tau and beta-amyloid: how well do these biomarkers reflect autopsy-confirmed dementia diagnoses? Arch Neuro/ 2003, 60:1696-1702.

41. Slaets S, Le Bastard N, Theuns J, Sleegers K, Verstraeten A, De Leenheir E, Luyckx J, Martin JJ, Van Broeckhoven C, Engelborghs S: Amyloid pathology influences abeta1-42 cerebrospinal fluid levels in dementia with lewy bodies. J Alzheimers Dis 2013, 35:137-146.

42. Bibl M, Mollenhauer B, Lewczuk P, Esselmann H, Wolf $\mathrm{S}$, Trenkwalder C, Otto M, Stiens G, Ruther E, Kornhuber J, Wiltfang J: Validation of amyloid-beta peptides in CSF diagnosis of neurodegenerative dementias. Mol Psychiatry 2007, 12:671-680.

43. Mollenhauer B, Esselmann H, Trenkwalder C, Schulz-Schaeffer W, Kretzschmar H, Otto M, Wiltfang J, Bibl M: CSF amyloid-beta peptides in neuropathologically diagnosed dementia with Lewy bodies and Alzheimer's disease. J Alzheimers Dis 2011, 24:383-391.

44. Portelius E, Brinkmalm G, Tran AJ, Zetterberg H, Westman-Brinkmalm A, Blennow K: Identification of novel APP/Abeta isoforms in human cerebrospinal fluid. Neurodegener Dis 2009, 6:87-94.

45. Cleveland DW, Spiegelman BM, Kirschner MW: Conservation of microtubule associated proteins. Isolation and characterization of tau and the high molecular weight microtubule associated protein from chicken brain and from mouse fibroblasts and comparison to the corresponding mammalian brain proteins. J Biol Chem 1979, 254:12670-12678.

46. Braak H, Braak E, Grundke-lqbal I, lqbal K: Occurrence of neuropil threads in the senile human brain and in Alzheimer's disease: a third location of paired helical filaments outside of neurofibrillary tangles and neuritic plaques. Neurosci Lett 1986, 65:351-355.

47. Grundke-labal I, labal K, Quinlan M, Tung YC, Zaidi MS, Wisniewski HM: Microtubule-associated protein tau. A component of Alzheimer paired helical filaments. J Biol Chem 1986, 261:6084-6089.

48. Lee VM, Goedert M, Trojanowski JQ: Neurodegenerative tauopathies. Annu Rev Neurosci 2001, 24:1121-1159.

49. Mollenhauer B, Cepek L, Bibl M, Wiltfang J, Schulz-Schaeffer WJ, Ciesielczyk B, Neumann M, Steinacker P, Kretzschmar HA, Poser S, Trenkwalder C, Otto M: Tau protein, Abeta42 and S-100B protein in cerebrospinal fluid of patients with dementia with Lewy bodies. Dement Geriatr Cogn Disord 2005, 19:164-170.

50. Parnetti L, Lanari A, Amici S, Gallai V, Vanmechelen E, Hulstaert F: CSF phosphorylated tau is a possible marker for discriminating Alzheimer's disease from dementia with Lewy bodies. Phospho-Tau International Study Group. Neurol Sci 2001, 22:77-78.

51. Merdes AR, Hansen LA, Jeste DV, Galasko D, Hofstetter CR, Ho GJ, Thal LJ, Corey-Bloom J: Influence of Alzheimer pathology on clinical diagnostic accuracy in dementia with Lewy bodies. Neurology 2003, 60:1586-1590.

52. Arima K, Hirai S, Sunohara N, Aoto K, Izumiyama Y, Ueda K, Ikeda K, Kawai M: Cellular co-localization of phosphorylated tau- and NACP/alpha-synuclein-epitopes in lewy bodies in sporadic Parkinson's disease and in dementia with Lewy bodies. Brain Res 1999, 843:53-61.

53. Hampel H, Goernitz A, Buerger K: Advances in the development of biomarkers for Alzheimer's disease: from CSF total tau and Abeta(1-42) proteins to phosphorylated tau protein. Brain Res Bull 2003, 61:243-253.

54. Blennow K, Wallin A, Agren H, Spenger C, Siegfried J, Vanmechelen E: Tau protein in cerebrospinal fluid: a biochemical marker for axonal degeneration in Alzheimer disease? Mol Chem Neuropathol 1995, 26:231-245.

55. Buerger K, Zinkowski R, Teipel SJ, Tapiola T, Arai H, Blennow K, Andreasen N, Hofmann-Kiefer K, DeBernardis J, Kerkman D, McCulloch C, Kohnken R, Padberg F, Pirttila T, Schapiro MB, Rapoport SI, Moller HJ, Davies P, Hampel H: Differential diagnosis of Alzheimer disease with cerebrospinal fluid levels of tau protein phosphorylated at threonine 231. Arch Neurol 2002, 59:1267-1272. 
56. Hu YY, He SS, Wang XC, Duan QH, Khatoon S, labal K, Grundke-labal I, Wang JZ: Elevated levels of phosphorylated neurofilament proteins in cerebrospinal fluid of Alzheimer disease patients. Neurosci Lett 2002, 320:156-160.

57. Itoh N, Arai H, Urakami K, Ishiguro K, Ohno H, Hampel H, Buerger K, Wiltfang J, Otto M, Kretzschmar H, Moeller HJ, Imagawa M, Kohno H, Nakashima K, Kuzuhara S, Sasaki H, Imahori K: Large-scale, multicenter study of cerebrospinal fluid tau protein phosphorylated at serine 199 for the antemortem diagnosis of Alzheimer's disease. Ann Neurol 2001, 50:150-156.

58. Chandra S, Gallardo G, Fernandez-Chacon R, Schluter OM, Sudhof TC: Alpha-synuclein cooperates with CSPalpha in preventing neurodegeneration. Cell 2005, 123:383-396.

59. Spillantini MG, Schmidt ML, Lee VM, Trojanowski JQ, Jakes R, Goedert M Alpha-synuclein in Lewy bodies. Nature 1997, 388:839-840

60. Gai WP, Power JH, Blumbergs PC, Blessing WW: Multiple-system atrophy: a new alpha-synuclein disease? Lancet 1998, 352:547-548.

61. El-Agnaf OM, Salem SA, Paleologou KE, Cooper LJ, Fullwood NJ, Gibson MJ, Curran MD, Court JA, Mann DM, Ikeda S, Cookson MR, Hardy J, Allsop D: Alpha-synuclein implicated in Parkinson's disease is present in extracellular biological fluids, including human plasma. Faseb J 2003, 17:1945-1947.

62. Lee HJ, Patel S, Lee SJ: Intravesicular localization and exocytosis of alpha-synuclein and its aggregates. J Neurosci 2005, 25:6016-6024.

63. Shi M, Bradner J, Hancock AM, Chung KA, Quinn JF, Peskind ER, Galasko D, Jankovic J, Zabetian CP, Kim HM, Leverenz JB, Montine TJ, Ginghina C, Kang UJ, Cain KC, Wang Y, Aasly J, Goldstein D, Zhang J: Cerebrospinal fluid biomarkers for Parkinson disease diagnosis and progression. Ann Neurol 2011, 69:570-580.

64. Aerts MB, Esselink RA, Abdo WF, Bloem BR, Verbeek MM: CSF alpha-synuclein does not differentiate between parkinsonian disorders. Neurobiol Aging 2011, 33:430.e1-3.

65. Mollenhauer B, El-Agnaf OM, Marcus K, Trenkwalder C, Schlossmacher MG: Quantification of alpha-synuclein in cerebrospinal fluid as a biomarker candidate: review of the literature and considerations for future studies. Biomark Med 2010, 4:683-699.

66. Kapaki E, Paraskevas GP, Emmanouilidou E, Vekrellis K: The diagnostic value of CSF alpha-synuclein in the differential diagnosis of dementia with Lewy bodies vs. normal subjects and patients with Alzheimer's disease. PLoS One 2013, 8:e81654.

67. Cantuti-Castelvetri I, Klucken J, Ingelsson M, Ramasamy K, McLean PJ, Frosch MP, Hyman BT, Standaert DG: Alpha-synuclein and chaperones in dementia with Lewy bodies. J Neuropathol Exp Neurol 2005, 64:1058-1066.

68. Beyer K, Humbert J, Ferrer A, Lao Jl, Carrato C, Lopez D, Ferrer I, Ariza A: Low alpha-synuclein 126 mRNA levels in dementia with Lewy bodies and Alzheimer disease. Neuroreport 2006, 17:1327-1330.

69. Anderson JP, Walker DE, Goldstein JM, de Laat R, Banducci K, Caccavello RJ, Barbour R, Huang J, Kling K, Lee M, Diep L, Keim PS, Shen X, Chataway T, Schlossmacher MG, Seubert P, Schenk D, Sinha S, Gai WP, Chilcote TJ: Phosphorylation of Ser 129 is the dominant pathological modification of alpha-synuclein in familial and sporadic Lewy body disease. J Biol Chem 2006, 281:29739-29752.

70. Chodobski A, Szmydynger-Chodobska J: Choroid plexus: target for polypeptides and site of their synthesis. MicrosC Res Tech 2001, 52:65-82.

71. Toledo JB, Korff A, Shaw LM, Trojanowski JQ, Zhang J: CSF alpha-synuclein improves diagnostic and prognostic performance of CSF tau and Abeta in Alzheimer's disease. Acta Neuropathol 2013, 126:683-697.

72. Mattsson N, Insel P, Tosun D, Zhang J, Jack CR Jr, Galasko D, Weiner M, Alzheimer's Disease Neuroimaging Initiative: Effects of baseline CSF alpha-synuclein on regional brain atrophy rates in healthy elders, mild cognitive impairment and Alzheimer's disease. PLoS One 2013, 8:e85443.

73. El-Agnaf OM, Salem SA, Paleologou KE, Curran MD, Gibson MJ, Court JA, Schlossmacher MG, Allsop D: Detection of oligomeric forms of alpha-synuclein protein in human plasma as a potential biomarker for Parkinson's disease. Faseb J 2006, 20:419-425.

74. Tokuda T, Qureshi MM, Ardah MT, Varghese S, Shehab SA, Kasai T, Ishigami N, Tamaoka A, Nakagawa M, El-Agnaf OM: Detection of elevated levels of \{alpha\}-synuclein oligomers in CSF from patients with Parkinson disease. Neurology 2010, 75:1766-1772.

75. Wennstrom M, Surova Y, Hall S, Nilsson C, Minthon L, Bostrom F, Hansson O, Nielsen HM: Low CSF levels of both alpha-synuclein and the alpha-synuclein cleaving enzyme neurosin in patients with synucleinopathy. PLoS One 2013, 8:e53250.
76. Waragai M, Wei J, Fujita M, Nakai M, Ho GJ, Masliah E, Akatsu H, Yamada T, Hashimoto M: Increased level of DJ-1 in the cerebrospinal fluids of sporadic Parkinson's disease. Biochem Biophys Res Commun 2006, 345:967-972.

77. Hong Z, Shi M, Chung KA, Quinn JF, Peskind ER, Galasko D, Jankovic J, Zabetian CP, Leverenz JB, Baird G, Montine TJ, Hancock AM, Hwang H, Pan C, Bradner J, Kang UJ, Jensen PH, Zhang J: DJ-1 and alpha-synuclein in human cerebrospinal fluid as biomarkers of Parkinson's disease. Brain 2010, 133:713-726.

78. Choi J, Sullards MC, Olzmann JA, Rees HD, Weintraub ST, Bostwick DE, Gearing M, Levey Al, Chin LS, Li L: Oxidative damage of DJ-1 is linked to sporadic Parkinson and Alzheimer diseases. J Biol Chem 2006, 281:10816-10824.

79. de Jong D, Jansen RW, Pijnenburg YA, van Geel WJ, Borm GF, Kremer HP, Verbeek MM: CSF neurofilament proteins in the differential diagnosis of dementia. J Neurol Neurosurg Psychiatry 2007, 78:936-938.

80. Ching GY, Liem RK: Assembly of type IV neuronal intermediate filaments in nonneuronal cells in the absence of preexisting cytoplasmic intermediate filaments. J Cell Biol 1993, 122:1323-1335.

81. Schmidt ML, Murray J, Lee VM, Hill WD, Wertkin A, Trojanowski JQ: Epitope map of neurofilament protein domains in cortical and peripheral nervous system Lewy bodies. Am J Pathol 1991, 139:53-65.

82. Storch J, Thumser AE: Tissue-specific functions in the fatty acid-binding protein family. J Biol Chem 2010, 285:32679-32683.

83. Cheon MS, Kim SH, Fountoulakis M, Lubec G: Heart type fatty acid binding protein (H-FABP) is decreased in brains of patients with Down syndrome and Alzheimer's disease. J Neural Transm Supp/ 2003, 67:225-234.

84. Steinacker $P$, Mollenhauer B, Bibl M, Cepek L, Esselmann H, Brechlin P, Lewczuk P, Poser S, Kretzschmar HA, Wiltfang J, Trenkwalder C, Otto M: Heart fatty acid binding protein as a potential diagnostic marker for neurodegenerative diseases. Neurosci Lett 2004, 370:36-39.

85. Mollenhauer B, Steinacker P, Bahn E, Bibl M, Brechlin P, Schlossmacher MG, Locascio JJ, Wiltfang J, Kretzschmar HA, Poser S, Trenkwalder C, Otto M: Serum heart-type fatty acid-binding protein and cerebrospinal fluid tau: marker candidates for dementia with Lewy bodies. Neurodegener Dis 2007, 4:366-375.

86. Aerts MB, Esselink RA, Claassen JA, Abdo WF, Bloem BR, Verbeek MM: CSF tau, Abeta42, and MHPG differentiate dementia with Lewy bodies from Alzheimer's disease. J Alzheimers Dis 2011, 27:377-384

87. Herbert MK, Aerts MB, Kuiperij HB, Claassen JA, Spies PE, Esselink RA, Bloem BR, Verbeek MM: Addition of MHPG to Alzheimer's disease biomarkers improves differentiation of dementia with Lewy bodies from Alzheimer's disease but not other dementias. Alzheimers Dement 2014, 10:448-455. e442.

88. Nielsen HM, Hall S, Surova Y, Nagga K, Nilsson C, Londos E, Minthon L, Hansson O, Wennstrom M: Low levels of soluble NG2 in cerebrospinal fluid from patients with dementia with Lewy bodies. J Alzheimers Dis 2014, 40:343-350.

89. Schultz K, Wiehager S, Nilsson K, Nielsen JE, Lindquist SG, Hjermind LE, Andersen BB, Wallin A, Nilsson C, Petersen A: Reduced CSF CART in dementia with Lewy bodies. Neurosci Lett 2009, 453:104-106.

90. Bostrom F, Hansson O, Gerhardsson L, Lundh T, Minthon L, Stomrud E, Zetterberg $\mathrm{H}$, Londos E: CSF Mg and $\mathrm{Ca}$ as diagnostic markers for dementia with Lewy bodies. Neurobiol Aging 2009, 30:1265-1271.

91. Ho GJ, Liang W, Waragai M, Sekiyama K, Masliah E, Hashimoto M: Bridging molecular genetics and biomarkers in lewy body and related disorders. Int J Alzheimers Dis 2011, 2011:842475.

92. Wada-Isoe K, Michio K, Imamura K, Nakaso K, Kusumi M, Kowa H, Nakashima K: Serum proteomic profiling of dementia with Lewy bodies: diagnostic potential of SELDI-TOF MS analysis. J Neural Transm 2007, 114:1579-1583.

93. Abdi F, Quinn JF, Jankovic J, McIntosh M, Leverenz JB, Peskind E, Nixon R, Nutt J, Chung K, Zabetian C, Samii A, Lin M, Hattan S, Pan C, Wang Y, Jin J, Zhu D, Li GJ, Liu Y, Waichunas D, Montine TJ, Zhang J: Detection of biomarkers with a multiplex quantitative proteomic platform in cerebrospinal fluid of patients with neurodegenerative disorders. J Alzheimers Dis 2006, 9:293-348.

94. Zhang J: Proteomics of human cerebrospinal fluid - the good, the bad, and the ugly. Proteomics Clin Appl 2007, 1:805-819.

95. Mollenhauer B, Schlossmacher MG: CSF synuclein: adding to the biomarker footprint of dementia with Lewy bodies. J Neurol Neurosurg Psychiatry 2010, 81:590-591.

doi:10.1186/s13195-014-0072-3

Cite this article as: Schade and Mollenhauer: Biomarkers in biological fluids for dementia with Lewy bodies. Alzheimer's Research \& Therapy 2014 6:72. 